feministas católicas, judeus belicistas, muçulmanos voltairianos, racistas libertários... A esquerda precisará aprender a manejar com delicadeza os paradoxos da inconsistência lógica. JAM conclui que chegou a hora de dar uma sepultura decente ao homem de esquerda!

Considerado um livro erudito foi recebido como uma pequena jóia da língua francesa, pela crítica.

Recebido em 1/8/2004.

Aprovado em 20/8/2004.

Tania Coelho dos Santos

taniacs@openlink.com.br

\section{AS MÚLTIPLAS DIMENSÕES DA TRANSFERÊNCIA NA CLÍNICA PSICANALÍTICA}

De corpos e afetos: transferências e clínica psicanalitica. Eliana Schueler

Reis. Rio de Janeiro: Contra Capa, 2004. $134 \mathrm{p}$.

\section{Ana Lila Lejarraga}

Psicanalista; doutora em Saúde Coletiva, IMS/Uerj; professora adjunta do Instituto de Psicologia, UFRJ.

Os "mais malignos demônios" são convocados no tratamento anímico, dizia Freud. As forças que agem no tratamento são perigosas, e tanto podem ser benéficas quanto destruidoras, dependendo da destreza de quem cura. Essa duplicidade já era conhecida pelos antigos gregos, que sabiam que o mesmo remédio que cura é o veneno que mata, designando ambos com o mesmo nome: phármakon.

O novo livro de Eliana Schueler Reis aborda essas poderosas forças postas em movimento na experiência da cura, nas fronteiras entre o corpo e a alma, que afetam a ambos os participantes do processo. O tema central do livro é a cura pela transferência, partindo da especificidade da clínica psicanalítica, mas visando uma reflexão mais ampla sobre a experiência da cura em geral.

No momento atual, em que os discursos da biomedicina e da psicofarmacologia desafiam a psicanálise, identificando fatos psíquicos a processos bioquímicos e neurológicos, a autora nos faz recordar o caráter híbrido de qualquer abordagem clínica, numa visão crítica dos procedimentos purificadores. Questionam-se tanto as tendências objetivadoras das novas tecnologias - que concebem o padecimento psíquico como fato objetivo, 
purificado de qualquer subjetividade quanto as propostas de tratamentos anímicos purificados das intensidades afetivas e dos corpos.

Retomam-se, neste estudo, as questões inaugurais e básicas da clínica psicanalítica: Como se transfere? Por que circuitos transitam as forças pulsionais no encontro transferencial? O que faz com que a transferência seja um processo subjetivador? O que se exige do clínico no processo terapêutico? Para respondêlas, Eliana Reis lança mão das contribuições de Ferenczi e do diálogo com outras áreas de saber, como os estudos sobre etologia humana, de Daniel Stern, e sobre estética, de José Gil. O conceito de transferência sairá enriquecido e redimensionado com esse diálogo, a partir do qual se desenvolvem hipóteses novas e originais.

A autora considera que a transferência não pode ser reduzida ao plano discursivo ou à simples repetição de lembranças infantis, explorando seus aspectos não verbais: os pequenos gestos, os ínfimos detalhes, os ruídos, os atos insignificantes, as manifestações corporais. Ferenczi já dirigia seu olhar para os sutis sinais expressivos que ocorriam durante as sessões — as impressões sensíveis não inscritas como traços mnésicos - privilegiando as intensidades afetivas mobilizadas na transferência.

Para trabalhar a percepção desses ínfimos sinais, Eliana Reis lança mão da noção de "pequenas percepções" de Leibniz, retomada e recriada por José Gil nos seus estudos sobre a experiência estética. Essas "pequenas percepções”, embora eficazes pelas suas conseqüências, não são apreensíveis de imediato pela consciência. É pelo olhar, diferente da visão objetivadora, que se captam as pequenas percepções, que criam atmosferas, produzin- do sentidos que nos afetam, embora sejam a-significantes do ponto de vista da estrutura lingüística. A autora considera que as pequenas percepções são próximas da noção do corpo erógeno freudiano, interpretando o corpo erógeno como um corpo sensível, com um regime de forças próprio, cujas marcas sensórias e perceptivas não são traduzidas, em sua maior parte, pela expressão verbal.

Para explorar essa dimensão corporal e as primeiras formas de experiência subjetiva não verbal, a autora utiliza os estudos de Daniel Stern sobre os afetos de vitalidade e sobre sintonia de afetos. Os afetos de vitalidade, primeiras marcas sensoriais apreendidas pelo sistema perceptivo inato do bebê, são afetos relacionados com os processos vitais, por meio dos quais modulam-se inconscientemente as relações com os outros. A sintonia de afeto refere-se a uma modalidade relacional pela qual a mãe pode captar e dar sentido aos mínimos sinais de seu bebê, estabelecendo canais de contato afetivo entre seus corpos. Essa sintonia, embora não seja total, permite apreender os afetos de vitalidade, o que remete à noção das pequenas percepções, já que a sintonia de afeto se funda nas pequenas percepções.

Com base nessas noções, entre outras, Eliana Reis desenvolve suas argumentações sobre o encontro transferencial e sua dimensão transformadora, num trabalho rigoroso e inovador.

A transferência não se restringe ao campo das representações, mas se constitui pelo detalhe, pelas pequenas percepções, pelas impressões sensíveis que não se registram como memória. A transferência, mais que reedição do passado, é concebida como um processo introjetivo e criador, em que se mobilizam e se transmudam afetos com efeitos transformadores. 
Nas palavras da autora: "Mais que uma simples reedição representacional dos conflitos infantis recalcados, a transferência se revela como a força capaz de produzir metamorfoses subjetivas que atingem corpo e alma como um campo de possíveis."

O tato ou a capacidade de "sentir com" do analista é repensada como a possibilidade analítica de sintonia de afetos, de ser sensível às pequenas percepções, apreendendo os afetos de vitalidade e as atmosferas.

Eliana Reis propõe ampliar a noção de "atenção flutuante" para um "olhar flutuante" que possa captar os pequenos gestos, as intensidades afetivas, a expressão do corpo e da voz, enfim, um olhar flutuante que apreenda os fenômenos de limiar que a visão objetivadora não vê. Ampliando e redefinindo vários conceitos da clínica psicanalítica, a autora reafirma a radicalidade do encontro transferencial na sua dimensão mais subjetiva e fundante, afetiva e corporal.

Embora a leitura deste livro seja aparentemente fácil, pela elegância e simplicidade do estilo, ela exige do leitor uma atenção e reflexão aprofundadas sobre as questões levantadas e as novas hipóteses propostas. As argumentações vão se costurando com sutileza, articulando conceitos psicanalíticos com outros saberes, o que produz, por pequenas modulações teóricas, por "detalhes", novas perspectivas teóricas e práticas. Pensamos que é uma leitura imprescindível, instigante e enriquecedora, para todos aqueles que se interessam pela clínica psicanalítica e pela experiência da cura de maneira geral.

Recebido em 28/8/2004.

Aprovado em 15/9/2004. 